\title{
ETS2 Gene
}

National Cancer Institute

\section{Source}

National Cancer Institute. ETS2 Gene. NCI Thesaurus. Code C18328.

This gene is involved in transcriptional activation and skeletal development. 